Удк 339.138

DOI https://doi.org/10.32851/2708-0366/2021.7.11

Пономаренко I.B.

кандидат економічних наук, доцент, Київський національний університет технологій та дизайну ORCID: https://orcid.org/0000-0003-3532-8332

Ponomarenko Ihor

Kyiv National University of Technologies and Design

\title{
ОСОБЛИВОСТІ ФОРМУВАННЯ МАРКЕТИНГОВИХ КОМУНІКАЦІЙ В УМОВАХ ЦИФРОВІЗАЦІї
}

\section{PECULIARITIES OF MARKETING COMMUNICATIONS FORMATION IN THE DIGITALIZATION CONDITIONS}

\begin{abstract}
У статті досліджено особливості використання сучасних маркетингових стратегій для налагодження ефективних комунікацій із иільовою аудиторією з урахуванням процесів діджиталізаиії. Установлено істотність зв'язку між пандемією COVID-19 та активізацією використання передових інструментів цчифрового маркетингу. Доведено істотний вплив сучасних інформаційно-комунікаційних технологій на зміни у поведіниі клієнтів та трансформацію ключових прочесів діяльності компаній із метою забезпечення високого рівня конкурентоспроможності на різних ринках. Визначено ефективність застосування алгоритмів машинного навчання під час забезпечення таргетингу рекламних повідомлень у мережі Інтернет. Розкрито особливості залучення лідерів думок для просування продукиії компаній у ичифровому середовищі. Установлено, щзо процеси діджиталізаиї сприяли появі віртуальних інфлюєнсерів, які мають велику кількість підписників у різних сочіальних мережах та використовуються у маркетингових кампаніях різноманітних брендів. Розкрито особливості трансформації соиіальних мереж на прикладі відеоконтенту.
\end{abstract}

Ключові слова: інновачї, комунікаџї, маркетинг, цчифровізація, цчільова аудиторія.

В статье исследованы особенности использования современных маркетинговых стратегий для налаживания эффективных коммуникаций с изелевой аудиторией с учетом процессов диджитализации. Установлена существенность связи между пандемией COVID-19 и активизацией использования передовых инструментов ичфрового маркетинга. Доказано существенное влияние современных информационно-коммуникаиионных технологий на изменения в поведении клиентов и трансформацию ключевых процессов деятельности компаний с иелью обеспечения высокого уровня конкурентоспособности на различных рынках. Определена эффективность применения алгоритмов машинного обучения при обеспечении таргетинга рекламных сообщений в сети Интернет. Раскрыты особенности привлечения лидеров мнений для продвижения продукции компаний в ичифровой среде. Установлено, что проиессы диджитализации способствовали появлению виртуальных инфлюенсеров, которье имеют большое количество подписчиков в разных сочиальных сетях и используются в маркетинговых кампаниях различных брендов. Раскрыты особенности трансформации социальных сетей на примере видеоконтента.

Ключевые слова: инновацчии, коммуникацฺи, маркетинг, цฺифровизация, ичелевая аудитория.

The article examines the features of using modern marketing strategies to establish effective communication with the target audience, taking into account the processes of digitalization. The link between the COVID-19 pandemic and the use of advanced digital marketing tools has been established. The significant influence of modern information and communication technologies on changes in customer behavior and transformation of key business processes of companies in order to ensure a high level of competitiveness in different markets is proved. The effectiveness of the application of machine learning algorithms in providing targeting of advertising messages on the Internet is determined. The peculiarities of attracting opinion leaders to promote the products of companies in the digital environment are revealed. In the process of finding opinion 
leaders to promote their products, companies need to decide on the social networks in which the target audience is located. It is also necessary to clearly define the niche of the product, which will correspond to the specialization of bloggers (beauty bloggers, gaming bloggers, coaching bloggers, travel bloggers, fitness bloggers, food bloggers, etc.). Particular attention should be paid to animals, which are popular among the vast majority of users of social networks. Companies attract popular animals to promote specialized products and related services among the target audience of certain social media. It was found that digitalization processes have contributed to the emergence of virtual influencers, who have a large number of subscribers in various social networks and are used in marketing campaigns of various brands. Peculiarities of social networks transformation on the example of video content are revealed. Social distancing due to the COVID-19 pandemic has contributed to the intensification of the e-commerce market. Using advanced digital marketing tools allows to transform traffic into sales of goods and services of an individual company. Implementing an effective business strategy in e-commerce involves the development of a flexible marketing strategy that will allow to quickly adapt to the needs of the target audience.

Key words: innovation, communications, marketing, digitalization, target audience.

Постановка проблеми. У сучасних умовах процеси діджиталізації призводять до появи комплексу позитивних та негативних проявів у діяльності компаній. Для досягнення довгострокового позитивного ефекту суб'єкти підприємницької діяльності повинні мінімізувати ризики, що пов'язані із запровадженням інноваційних технологій, та намагатися використати наявні можливості. Серед важливих напрямів діяльності компанії слід звернути увагу на дослідження можливостей застосування цифрового маркетингу.

Аналіз останніх досліджень і публікацій. Різні аспекти оптимізації використання основних інструментів цифрового маркетингу висвітлено у працях таких учених, як К. Ванг, Дж. Габрієлле, Д. Еванс, П. Сінгх, К. Родден, Е. Тандок, Р. Томас, Дж. Ярвінен, Б. Янсен та ін.

Формулювання цілей статті. Розвиток наукової думки у сфери цифрового маркетингу призвів до появи великої кількості тематичних наукових праць, проте інтенсифікація науково-технічного процесу та віртуалізація соціально-економічних явищ i процесів передбачають дослідження ключових трендів щодо налагодження ефективних та довгострокових комунікацій між компаніями і клієнтами в мережі Інтернет.

Виклад основного матеріалу. Активне запровадження передових технологій на глобальному та національному рівнях призводить до трансформації соціально-економічних відносин у суспільстві. Цифровізація прискорює зміни в усіх видах економічної діяльності, виступаючи рушієм революційних перетворень існуючих виробничих процесів. Істотний вплив на процеси діджиталізації спричинила пандемія COVID-19, наслідки якої спонукали значну кількість населення перебувати в умовах соціального дистанціювання, активно використовуючи цифрові технології у повсякденному житті та в ході виконання професійних обов'язків [1].

Проникнення сучасних інформаційно-комунікаційних процесів у різних країнах світу характеризується різним рівнем залучення широких верств населення та розподілом за регіонами країни, що свідчить про наявність нерівності у доступі окремих категорій громадян до цифрових технологій. Відповідно, існує потреба у реалізації державних програм щодо спрощення доступу до інноваційних технологій, особливо в країнах, що розвиваються. Особливу увагу доцільно приділити забезпеченню справедливого доступу до цифрових продуктів у сфері охорони здоров'я та системі освітніх послуг.

Діджиталізація призводить до трансформації існуючого ринку, збільшуючи попит на інноваційні професії, та поступового нівелювання доцільності використання застарілих умінь і навичок. Серед негативних наслідків зазначеного процесу слід відзначити зростання цифрового безробіття внаслідок заміни людської праці на автоматизоване обладнання та активного розвитку штучного інтелекту. Інновації змушують робочу силу переорієнтовуватися з одних професій на інші, проходячи відповідний 
процес навчання та адаптації, що деструктивно впливає на осіб старших вікових груп працездатного віку та погіршує позиції даної категорії на ринку праці.

Цифровізація впливає на особливості функціонування суб'єктів підприємницької діяльності, які для забезпечення високого рівня конкурентоспроможності на певних ринках активно впроваджують інноваційні технології у різноманітні процеси. Розроблення та впровадження інноваційних підходів до функціонування дають можливість компаніям оптимізувати ключові процеси та створюють передумови для ефективного функціонування у довгостроковій перспективі. Виведення передових продуктів на ринок сприяє посиленню рівня конкурентоспроможності та зростанню попиту на товари чи послуги відповідної компанії.

Одним із напрямів оптимізації діяльності компанії в умовах цифровізації виступає маркетинг, який дає змогу розширювати цільову аудиторію та налагоджувати тісні комунікації на довготривалій основі. Побудова та реалізація ефективної маркетингової стратегії в умовах цифровізації дають змогу оптимізувати підприємницьку структуру, забезпечивши відповідний рівень гнучкості та адаптивності до чинників зовнішнього середовища.

Переорієнтація значної кількості населення на мережу Інтернет призвела до трансформації ринку реклами зі збільшенням частки відповідного інформаційного контенту у цифровому середовищі. Усвідомлення нових реалій змушує велику кількість брендів зосереджуватися на формуванні діджиталізованих рекламних бюджетів, використовуючи офлайн-канали комунікацій за залишковим принципом. Слід відзначити, що окреслений підхід раціонально застосовувати лише за умови перебування переважної частини потенційних клієнтів у мережі Інтернет. Для ефективного розповсюдження рекламних повідомлень компанії мають можливість використовувати спеціалізовані платформи (Google Ads, Bing Ads, Facebook Ads, Instagram Ads тощо). Завдяки можливості здійснювати велику кількість налаштувань, що включають геопозицію та систему соціально-економічних характеристик цільової аудиторії, вдається досягти високого рівня охоплення потенційних клієнтів тематичним контентом. Поряд із цим спеціалізовані платформи надають можливість реалізовувати таку сучасну рекламну модель, як оплата компанією за клік (СРС), тобто грошові кошти знімаються з рахунка лише за умови переходу потенційного клієнта за посиланням для ознайомлення з відповідним інформаційним повідомленням. Сервіси надають можливість компаніям отримати детальну статистичну інформацію щодо ефективності розміщення повідомлень про продукцію та визначати шляхи оптимізації використання рекламного бюджету. Використання програматик-реклами, яка базується на застосуванні штучного інтелекту в маркетингу, дає змогу нівелювати людський фактор та підвищити ефективність закупки рекламного контенту за системою аукціонів. Розвиток ринку реклами у цифровому середовищі дає змогу поступово відмовлятися від формування системи метрик окремими фахівцями на основі їх практичного та теоретичного досвіду, переорієнтувавшись на алгоритми глибокого навчання, які збирають усебічну та оперативну інформацію про потенційних клієнтів і приймають рішення про доцільність демонстрації тематичного контенту за певною ціною. Компанії розглядають штучний інтелект як дієвий інструмент підвищення ефективності таргетингу в процесі ідентифікації цільової аудиторії рекламних повідомлень певного тематичного напряму [2].

Значного розповсюдження в Інтернеті набуває долучення інфлюенсерів для просування певних товарів та послуг до кінцевих споживачів. Лідери думок у різних сферах володіють певною цільовою аудиторією, привертаючи увагу спеціалізованим тематичним контентом (фото- та відеоматеріали, текстові матеріали та ін.). Рівень популярності окремого інфлюєнсера серед підписників тісно корелює з вартістю залучення до просування рекламного контенту. У 2020 р. американо-канадійський актор Двейн Джонсон став лідером за вартістю розміщення поста з рекламним повідомленням в 
Instagram (1 млн дол. США за один пост), друге місце посіла американська модель Кайлі Дженнер (986 тис дол. США за один пост), третє місце належить португальському футболісту Кріштіану Роналду (889 тис дол. США за один пост) [3; 4].

Ефективність залучення інфлюенсерів можливо прослідкувати на прикладі співпраці між корейським гуртом BTS та McDonald's шляхом виведення на ринок меню The BTS Meal. Учасники гурту у Facebook зображені з окремими стравами даного меню та виражають задоволеність від споживання продукції McDonald's. Велика популярність гурту BTS у світі призвела до зростання продажів McDonald's: у США у травні 2021 р. впродовж першого тижня реалізації The BTS Meal кількість відвідувачів закладів харчування компанії зросла на $12 \%$; істотний попит на меню в Індонезії призвів до закриття низки закладів у країні 9 червня поточного року та тимчасової переорієнтації на доставку за допомогою кур'єрських служб [5].

Переважна більшість компаній не має можливості залучати високооплачуваних зірок зі сфери шоу-бізнесу та спорту, тому орієнтується на лідерів думок із меншою кількістю підписників та відповідною вартістю рекламних послуг. Пошук лідерів думок для просування продукції у соціальних мережах можливо здійснювати за допомогою геотегів або хештегів, спеціалізованих сторінок чи сервісів.

Компаніям у процесі пошуку лідерів думок для просування продукції необхідно визначитися із соціальними мережами, в яких знаходиться цільова аудиторія. Також необхідно чітко визначити нішу товару, яка відповідатиме спеціалізації блогерів (б'юті-блогери, геймінг-блогери, коучинг-блогери, тревел-блогери, фітнес-блогери, фуд-блогери та ін.). Окрему увагу необхідно звернути на тварин, які користуються популярністю серед переважної більшості відвідувачів соціальних мереж. Компанії залучають популярних тварин для просування спеціалізованої продукції та супутніх послуг серед цільової аудиторії певних соціальних медіа. Серед лідерів за прихильністю користувачів в Instagram слід звернути увагу на песика JiffPom $(10,2$ млн підписників), кішку nala_cat (4,3 млн підписників), лисицю juniperfoxx (3,0 млн підписників), мавпочку realdiddykong (857 тис підписників) [6].

Процеси діджиталізації сприяли появі віртуальних інфлюенсерів, які поступово набирають популярність та мають велику кількість підписників у різних соціальних мережах. Вигадані, або CGI, інфлюенсери - це створені за допомогою комп'ютерної графіки персонажі, які активно взаємодіють із цільовою аудиторією у соціальних медіа шляхом демонстрації вигаданого діджиталізованого життя та інших супутніх процесів, що користуються попитом у окремих груп користувачів.

У мережі Instagram лідерами серед віртуальних лідерів думок є Ліл Мікела (3 млн підписників), Бермуда (285 тис підписників), Шуду (218 тис підписників). У рекламній кампанії Calvin Klein в Instagram прийняли участь Белла Хадід та Ліл Мікела, що дало змогу досягти значних успіхів у процесі взаємодії із цільовою аудиторією. Міжнародні компанії в умовах діджиталізації створюють віртуальні моделі видатних особистостей. Так, Kentucky Fried Chicken представила 3D-модель засновника мережі ресторанів Гарланда Девіда Сандерса (полковника Сандерса). Активний розвиток інноваційних технологій дає можливість малим та середнім компаніям отримати доступ до послуг модельних агентств із 3D-моделями, які можливо одягти в оцифровану продукцію відповідних брендів [7].

Соціальне дистанціювання внаслідок пандемії COVID-19 сприяло активізації розвитку ринку електронної комерції. Використання передових інструментів цифрового маркетингу дає змогу трансформувати трафік продажу товарів та послуг окремої компанії. Реалізація ефективної бізнес-стратегії у рамках електронної комерції передбачає розроблення гнучкої маркетингової стратегії, яка дасть змогу дуже швидко адаптуватися до потреб цільової аудиторії. Поряд із вибором ефективних інструментів цифрового маркетингу доречно приділяти значну увагу створенню та розповсюдженню 
тематичного контенту з метою постійного утримання уваги потенційних клієнтів та формування усвідомлення цінності для користувачів унаслідок відвідування вебресурсів компанії. Додаток Instagram дає змогу не лише розміщувати тематичну інформацію, а й використовувати кнопку магазину у нижній навігаційній панелі. Використовуючи тематичні акаунти, вдається залучити підписників для ознайомлення 3 контентом, який певним чином пов'язаний з окремими продуктами, та стимулювати до здійснення покупки безпосередньо на сторінці. Доцільно приділяти увагу розмітці продуктів у публікаціях та сторіс, що дає змогу збільшити рівень ідентифікації продуктів потенційними клієнтами. До ефективних підходів до просування продукції також відноситься залучення клієнтів, які діляться власним досвідом користування продукцією брендів шляхом розміщення відповідних фото- та відеоматеріалів, а також додавання позитивних коментарів.

Обмеженість контактів та активний розвиток цифрових технологій дали змогу компаніям збирати велику кількість потенційних клієнтів завдяки проведенню віртуальних подій. Наприклад, традиційні презентації корпорації Apple набули нового вираження внаслідок використання формату віртуальних подій, що передбачає відсутність аудиторії на території Apple Park. Компанія демонструє соціальну відповідальність у сфері протидії розповсюдженню COVID-19, використовуючи інноваційні підходи для комунікацій із користувачами та демонстрації сучасних продуктів. Серед останніх віртуальних подій слід відзначити презентацію Apple 21 квітня (iMac, iPad Pro, iPhone 12 фіолетового кольору, AirTag, Apple TV 4K) та 7-11 червня 2021 p. (iOS 15, iPadOS 15, macOS Monterey, watchOS 8, tvOS 15).

Соціальні мережі використовуються компаніями для реалізації комплексних маркетингових стратегій упродовж тривалого періоду часу завдяки наявності у даних сервісах великої кількості потенційних клієнтів. Середовище соціальних медіа характеризується змінністю завдяки трансформації функціонування окремих мереж, а також виходу на ринок нових гравців. У середині 2018 р. на міжнародний рівень було виведено китайський сервіс із демонстрації коротких відео TikTok, який набрав популярності серед великої кількості користувачів, переважно тінейджерського віку. Представлений сервіс розглядається як певний конкурент YouTube у ніші нетривалого за часом розважального відеоконтенту. Для забезпечення конкурентних переваг відносно TikTok у 2021 р. почалося бета-тестування сервісу YouTube Shorts, який передбачає використання лише смартфону для створення коротких відео та швидке розміщення нового контенту на YouTube. Ураховуючи велику популярність відеоконтенту серед користувачів, компанії активно застосовують представлений інструмент цифрового маркетингу для налагодження комунікацій із цільовою аудиторією. За умови вдалого просування та позиціювання YouTube Shorts стане важливим елементом маркетингових стратегій компаній у найближчій перспективі.

Прикладом швидких трансформацій уподобань користувачів в умовах діджиталізації є неочікуване зростання Clubhouse - закритої соціальної мережі для голосового спілкування. У січні 2021 р. чисельність користувачів даної мережі нараховувала близько 2 млн осіб, а в лютому поточного року аудиторія зросла до 10 млн осіб. Закрита соціальна мережа надає користувачам можливість долучитися до спілкування 3 різними видатними особистостями, серед яких особливу увагу доцільно звернути на Ілона Маска та Марка Цукерберга [8].

Компанії залучають високооплачуваних модераторів для взаємодії із цільовою аудиторією, зацікавлюючи потенційних клієнтів у живому спілкуванні та збільшуючи їхній інтерес стосовно дотичних до брендів питань. Політика забезпечення невимушеної поведінки та можливість безпосередньо спілкуватися з лідерами думок дають можливість створювати ефективні та довгострокові комунікації між компаніями і клієнтами. 
Висновки. Отже, процеси діджиталізації призводять до істотної трансформації маркетингових стратегій компаній на постійній основі. Забезпечення високого рівня конкурентоспроможності вимагає постійного моніторингу ринку технологій та ідентифікації перспективних продуктів, які доцільно використовувати для досягнення довгострокових цілей. Компанії повинні усвідомлювати цінність комунікацій у цифровому середовищі та працювати над збільшенням кількості підписників, які з високим рівнем імовірності приноситимуть прибуток на довгостроковій основі за умови використання науково обгрунтованих методів стимулювання клієнтів до здійснення цільових дій. Окрему увагу доцільно приділяти питанням використання методів машинного навчання для підвищення ефективності використання інструментів цифрового маркетингу.

\section{Список використаних джерел:}

1. How COVID-19 Changed Marketing. URL: https://www.cmswire.com/digital-marketing/ how-covid-19-changed-marketing.

2. State of Digital Advertising 2021. URL: https://www.criteo.com/state-of-digital-advertisingreport-2021.

3. The World's Top 50 Influencers Across Social Media Platforms. URL: https://www.visualcapitalist.com/worlds-top-50-influencers-across-social-media-platforms.

4. 15 Highest Paid Celebrities on Instagram. URL: https://manofmany.com/lifestyle/highestpaid-celebrities-instagram.

5. McDonald's new BTS meal is already outpacing the hit Travis Scott meal in popularity. URL: https://www.businessinsider.com/mcdonalds-bts-meal-drives-traffic-to-restaurants-over-travisscott-meal-2021-6? $\mathrm{r}=\mathrm{US} \& \mathrm{IR}=\mathrm{T}$.

6. XX 10 of The Most Famous Pets on Instagram Right Now. URL: https://influencermatchmaker. co.uk/blog/10-most-famous-pets-instagram-right-now.

7. 5 CGI influencers to follow on Instagram. URL: https://hashtaglegend.com/culture/5-cgiinfluencers-instagram-miquela-shudu-imma.

8. How To Use Clubhouse For Business Growth. URL: https://www.forbes.com/sites/forbesbusin esscouncil/2021/02/12/how-to-use-clubhouse-for-business-growth/?sh=4211 fde026b2.

\section{References:}

1. How COVID-19 Changed Marketing. Available at: https://www.cmswire.com/digital-marketing/how-covid-19-changed-marketing.

2. State of Digital Advertising 2021. Available at: https://www.criteo.com/state-of-digital-advertising-report-2021.

3. The World's Top 50 Influencers Across Social Media Platforms. Available at: https://www.visualcapitalist.com/worlds-top-50-influencers-across-social-media-platforms.

4. 15 Highest Paid Celebrities on Instagram. Available at: https://manofmany.com/lifestyle/highest-paid-celebrities-instagram.

5. McDonald's new BTS meal is already outpacing the hit Travis Scott meal in popularity. Available at: https://www.businessinsider.com/mcdonalds-bts-meal-drives-traffic-to-restaurants-over-travisscott-meal-2021-6? $\mathrm{r}=\mathrm{US} \& \mathrm{IR}=\mathrm{T}$.

6. XX 10 of The Most Famous Pets on Instagram Right Now. Available at: https://influencermatchmaker.co.uk/blog/10-most-famous-pets-instagram-right-now.

7. 5 CGI influencers to follow on Instagram. Available at: https://hashtaglegend.com/culture/5-cgi-influencers-instagram-miquela-shudu-imma.

8. How To Use Clubhouse For Business Growth. Available at: https:/www.forbes.com/sites/ forbesbusinesscouncil/2021/02/12/how-to-use-clubhouse-for-business-growth/?sh=4211 fde026b2. 